\title{
CHARACTERISTICS OF FLOWING SNOW AND AVALANCHE IMPACT PRESSURES
}

\author{
by
}

\author{
D. M. MCClung AND P. A. SCHAERER
}

National Research Council, 3904 West 4th Avenue, Vancouver, BC, V6R 1P5

\begin{abstract}
Experimental data on avalanche impact pressures and speeds from an avalanche path at Rogers Pass, B.C., are presented for both dry and wet avalanches. Data from small load cells $\left(645 \mathrm{~mm}^{2}\right.$ surface) at various heights through the vertical cross-section of the avalanches show that the frequency of particle impact and hence flow density increases rapidly from top to bottom of the flow.

Data from a large circular impact plate (196 000 $\mathrm{mm}^{2}$ ) just above the ground surface show that dry avalanches have relatively higher peak pressures and relatively lower average pressures than wet avalanches for a given speed. Longitudinal wave-like characteristics in the flow may be seen for both wet and dry avalanches, but they appear to be the exception rather than the rule.

Comparison of pressure results with those of other studies shows good agreement for peak pressures, but average pressures are generally less than those of previous studies. This discrepancy is attributed to the past use of cells for which loading surface size approached typical particle size. The size effect may be demonstrated by comparison of small cell data with results from the large impact plate at Rogers Pass.
\end{abstract}

\section{INTRODUCTION}

Field measurements of impact pressures and speeds of avalanches are necessary to provide information about expected dynamic loading on structures placed in their paths. Coupled with observations of avalanches, such data also supply information about the related problem of formulation of avalanche dynamics models. Owing to the experimental difficulties involved and the necessity for making studies under full-scale conditions, there is a scarcity of usable data regarding this important applied problem. With this in mind the avalanche research group of the National Research Council of Canada has carried out observations of avalanche impact pressures and speeds for several years.

The impact pressure measurements described in this paper differ from those of most other studies because the impact loading surface is usually much larger than the size of typical avalanche debris particles. Enough data are now available to indicate trends in characterisitics of both wet and dry avalanches. They reveal that mechanical properties of wet and dry flowing snow may differ considerably. Flow characteristics and impact pressures, together with supporting field observations, indicate some important trends relevant to the choice of avalanche type for design impact pressures and maximum runout distances.

\section{CHARACTERISTICS OF OBSERVATION SITE AND AVALANCHES}

The observations were obtained in the Tupper No 1 avalanche path at Rogers Pass in the Selkirk Mountains of British Columbia. It is characterized by a vertical drop of about $1000 \mathrm{~m}$ and a long straight gully about $25 \mathrm{~m}$ wide and $500 \mathrm{~m}$ long at an incline of 35 deg. Pressure observations were made at the end of the gully. The avalanches occurred naturally, starting in several locations high on the mountainside. For the five years of the study (1979-1984) 95 avalanches were observed in this path, but only 12 (Table 1) yielded pressure information.

Of the 95 avalanches, $55 \%$ contained dry debris with an average density of particles in the deposit of $330 \mathrm{~kg} / \mathrm{m}^{3} ; 24 \%$ had moist debris with average particle density $420 \mathrm{~kg} / \mathrm{m}^{3}$, and $21 \%$ had wet debris with average particle density $500 \mathrm{~kg} / \mathrm{m}^{3}$. The overall average debris particle density was $390 \mathrm{~kg} / \mathrm{m}^{3}$, ranging from $180 \mathrm{~kg} / \mathrm{m}^{3}$ (small dry avalanche) to $590 \mathrm{~kg} / \mathrm{m}^{3}$ (wet avalanche). Field measurements showed dry debris with densities as high as $500 \mathrm{~kg} / \mathrm{m}^{3}$, indicating that the physical situation is not so simple as these averages seem to imply. The average avalanche mass for the 95 deposits was $1200 \mathrm{t}$, with a range from $10 \mathrm{t}$ (minumum put in records) to 14 $000 \mathrm{t}$. The total recorded mass of snow debris per year averaged about $23000 \mathrm{t}$.

\section{INSTRUMENTATION}

The experimental set-up comprised two types of load cell mounted on steel frames high enough on the mountain to prevent avalanche debris from collecting there. A series of five load cells mounted on a $5.2-\mathrm{m}$ high steel frame yielded information about avalanche flow characteristics. These cells had $645-\mathrm{mm}^{2}$ disc-shaped surfaces and were placed at various heights from 0.2 to $2 \mathrm{~m}$ above ground or snow surface, perpendicular to the flow direction (Schaerer and Salway 1980).

In order to obtain realistic impact pressures and to assess the effects of loading surface size a large circular aluminum plate (diameter $0.5 \mathrm{~m}$, thickness $25.4 \mathrm{~mm}$ ) was installed on a steel frame next to the small cell pressure stand in December 1979. The bottom of the plate, which was originally supported by four load cells with $110 \mathrm{kN}$ force capacity each, was about $0.2 \mathrm{~m}$ above the ground. The cells were very soon destroyed by a high pressure event, but the plate was re-installed in November 1980 with three large load cells mounted in an equilateral triangle pattern (side dimension $0.154 \mathrm{~m}$ ) around the centre of the plate. The cells are Strainsert universal flat load cells with a maximum capacity of $110 \mathrm{kN}$ each and a natural frequency of about $2000 \mathrm{~Hz}$ with the loading plate installed. The cells have a flat frequency response in the range $0-100 \mathrm{~Hz}$ with the loading plate installed, and were statically calibrated in the laboratory using the same electronic recording system as was used in the field.

Reliability of the large plate system and eccentricity of avalanche loading were checked by recording the output of each cell separately and the output of all three cells tied together. Actual records from avalanches showed a maximum difference of $20 \%$ between average pressures determined by adding pressures from the individual cells and values obtained from the three tied together. This analysis also showed that the pressures appeared to be applied fairly evenly over the face of the plate.

The speeds of avalanches approaching the pressure stands were estimated using geophones coupled to the rock in the gully at depths of about $0.15 \mathrm{~m}$ below the 
ground surface. These geophones were placed at distances varying from about $85 \mathrm{~m}$ above the pressure stands to beside them. Salway (1978) and Schaerer and Salway (1980) have discussed the method and equipment in detail and presented typical records.

It should be recognized that the speeds of avalanche debris determined by geophones are difficult to quantify and are subject to inaccuracy because an avalanche can excite them before they have been reached. If a geophone has high sensitivity, the accuracy is very poor. Another problem is that snow of ten collects higher up in the gully, making it impossible to detect avalanches late in the winter. The geophone data, therefore, are not accurate enough to provide information on velocity surges inside a debris wave or avalanche. Normally, information about frontal speeds only is provided. The speed information in this paper therefore refers to frontal speed of avalanches or frontal speeds of waves in avalanches for those avalanches that consist of a series of waves of debris.

Geophones placed high in the gully were also used to trigger the tape recording system before the pressure stands had been struck. This triggering system was discussed by Salway (1978) and by Schaerer and Salway (1980).

\section{RESULTS}

Small cells

Small cells with an effective loading surface of only $645 \mathrm{~mm}^{2}$ do not provide accurate estimates of impact pressures, because the typical particle size in avalanche flows usually exceeds the size of the loading surface. The small cells can provide descriptive information about frequency of particle impact and therefore of flow density as a function of depth if it is assumed that all debris particles have the same density. Field measurements indicate that this is a good assumption. Data from the small cells are illustrated in Figures 1 and 2 respectively, for avalanches with moist and wet debris in the deposits. Figure 1 shows a trend, observed in all pressure records to date, that implies

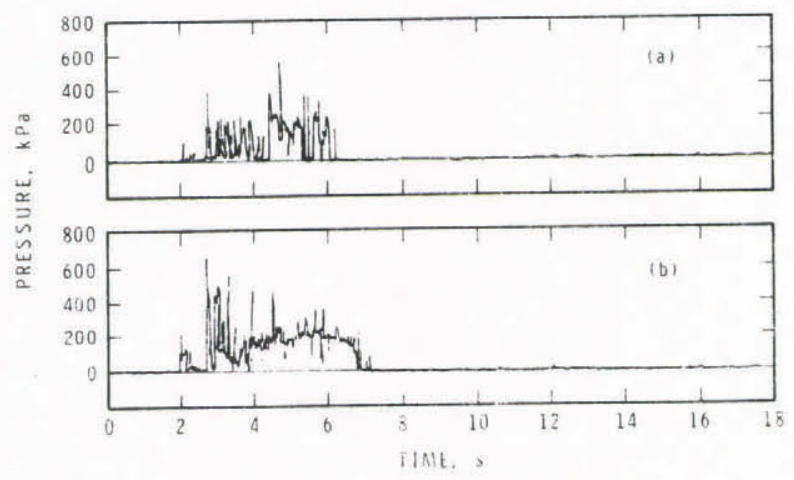

Fig.1a. Pressure record for avalanche with moist debris in the deposit from a small cell $0.70 \mathrm{~m}$ above the ground (Avalanche 81-12-09, No.1).

Fig.1b. Pressure record for avalanche with moist debris in the deposit from a small cell $0.45 \mathrm{~m}$ above the ground (Avalanche 81-12-09, No.1). increase of flow density with depth through the flow at the measuring site.

Figure 2 shows gaps in the debris flow, also mentioned by Salway (1978) and by Schaerer and Salway (1980). This effect is evident in data reported from France (Bon Mardion and others 1974) for both wet and dry avalanches. For the Rogers Pass data, however, this wave-like behaviour is the exception rather than the rule.

The small cells may also provide information about the depth of the dense, flowing core of the avalanche. Above the core only sporadic hits are recorded by the impact cells. For the Tupper 1 path the results to date show that this flow height varies from 0.5 to $2 \mathrm{~m}$, for estimated speeds of 8 to $47 \mathrm{~m} / \mathrm{s}$. Schaerer and Salway (1980) have given estimates of flow depths for avalanches occurring at this site.

Field observations show that dry avalanches are of ten enveloped by snow dust clouds consisting of small material suspended by turbulent eddies, whereas wet avalanches do not display such characteristics. This, coupled with data from the small cells, indicates that most large, dry avalanches have a structure that could be described by terminology used in sediment transport theory: a dense flowing core (bed load) enveloped by a powder cloud (suspended load). To date, data have been obtained from only one avalanche that might be termed a powder avalanche in which the bed load is absent. Field experience shows that this type of avalanche may reach fairly high speeds but is much less serious in terms of its destructive effects. Data presented for the powder avalanche in the next section support these field observations.

\section{Large Plate}

Figures 3 and 4 show pressure records for avalanches with, respectively, moist and wet debris in their deposits. Together with Figures 1 and 2, they illustrate the effect of loading surface size. Analysis of

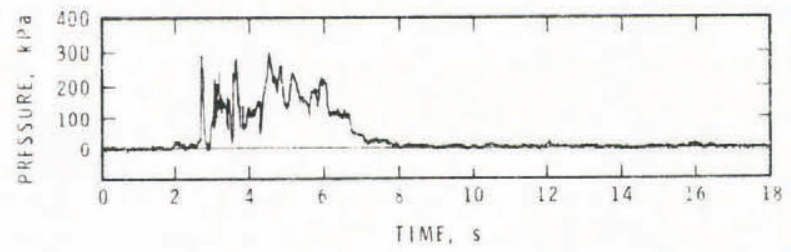

Fig.3. Pressure record for avalanche with moist debris in the deposit, from the large plate; compare with record in Fig.1 (Avalanche 81-12-09, No.1).

the pressure peaks shows that the large plate gives lower values by roughly an order of magnitude for the wet avalanche and in the order of a factor of 2 for the moist avalanche. Other data indicate that the size effect is usually more pronounced for wet avalanches, possibly owing to larger particles on average. For comparison, Figure 5 is a pressure record of a dry avalanche.

Figures 3, 4 and 5 also show features typical of dry and wet avalanches observed in data from the small cells. Generally, dry avalanches have higher peak pressures and relatively lower average pressures, resulting in higher levels of fluctuation than for wet avalanches. There is a tendency for the highest pressures to occur in the first half of the

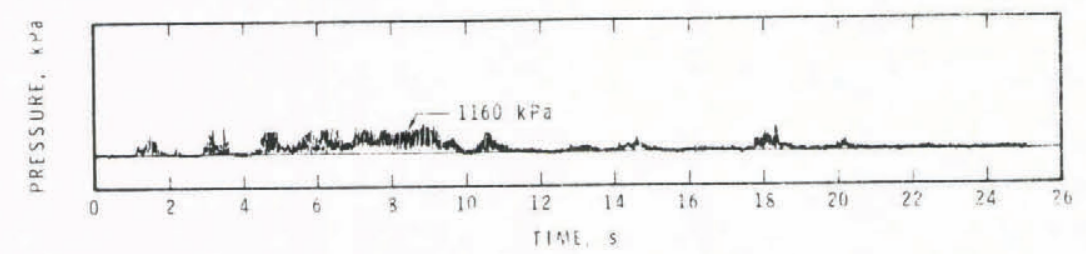

Fig.2. Pressure record from wet avalanche recorded by a small cell $0.70 \mathrm{~m}$ above the ground, showing wave-like behaviour (Avalanche 80-12-26, No.4). 


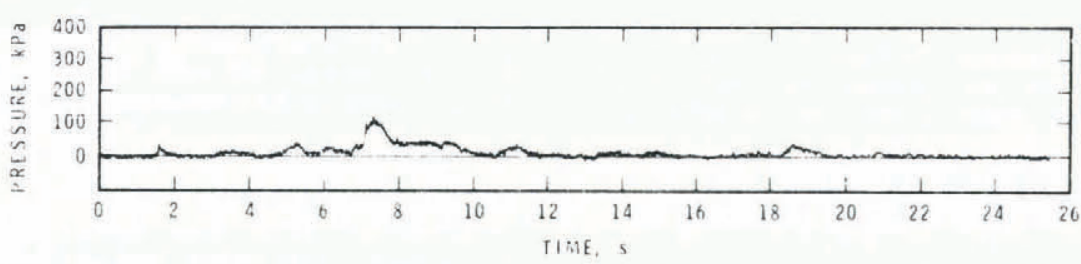

Fig 4. Pressure record for wet avalanche, from the large plate; compare with record in Fig. 2 (Avalanche 82-01-2, No.1).

flow. Records with the highest pressure at the head of the flow are the exception rather than the rule. There is a considerable variation of position of peak pressure in the data records collected to date.

All data from the large plate are listed in Table 1, with values for maximum or peak pressures $\mathrm{P}_{\mathrm{M}}(\mathrm{Pa})$, average pressure $\overline{\mathrm{P}}(\mathrm{Pa})$, speed $\mathrm{V}(\mathrm{m} / \mathrm{s})$, density of deposit $\rho_{D}\left(\mathrm{~kg} / \mathrm{m}^{3}\right)$, free water content of debris $(D=$ dry, $M=$ moist, $W=$ wet), and mass of deposit (tonnes). Values of $\mathrm{P}_{\mathrm{M}}$ and $\overline{\mathrm{P}}$ were determined by examination of calibrated printouts of the pressure records. Peak pressure was defined as the highest instantaneous value of the pressure (spike height) in the pressure record. Values of $\overline{\mathrm{P}}$ were determined

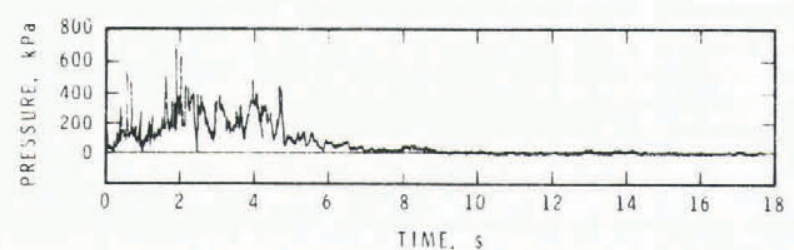

Fig.5. Pressure record for dry avalanche, from the large plate (Avalanche 82-01-23, No.1).

TABLE 1. OBSERVATIONS FROM THE LARGE PLATE, ROGERS PASS, TUPPER NO. 1.
Date

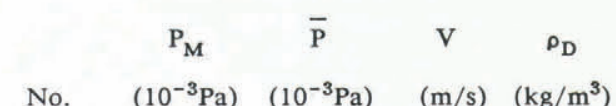
Free-water
content of
Mass
Duration
No. $\quad\left(10^{-3} \mathrm{~Pa}\right) \quad\left(10^{-3} \mathrm{~Pa}\right) \quad(\mathrm{m} / \mathrm{s}) \quad\left(\mathrm{kg} / \mathrm{m}^{3}\right)$ debris
(
(s)

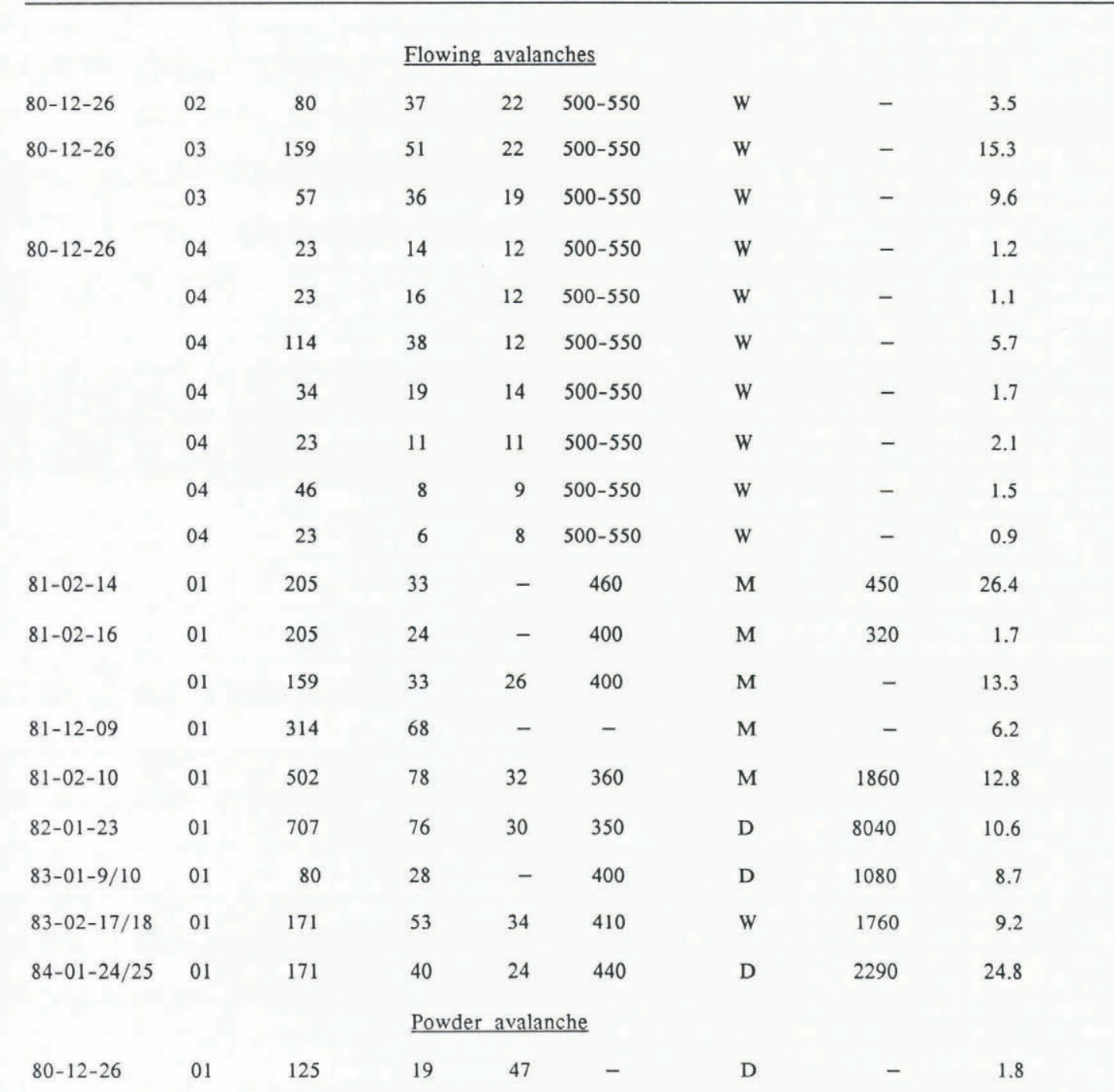


by using a calibrated planimeter. Estimates of $\rho_{\mathrm{D}}$ were made using a standard Swiss snow density kit $\left(500 \mathrm{~cm}^{3}\right)$. Gaps in the data indicate that it was not possible to determine values.

The deposit mass is the most difficult parameter to measure at Tupper No 1 because there are often several avalanches per day and it is not always possible to determine which pressure record belongs to which of the deposits. The frontal speeds, V, are given for either individual debris waves or for the avalanche as a whole if the debris came only in one wave. A debris wave was considered finished when the pressure dropped to zero on the large plate. Several avalanches showed a wave-like structure, but it was only possible to determine speeds of individual waves for two of them $(80-12-26$ No 4 , and 81-02-16, No 1).

One avalanche (80-12-26, No 1$)$ is considered to be a powder avalanche. The data from this event imply that it did not have a dense flowing core like the other avalanches. Figure 6 shows the pressure record, which displays a wave-like character.

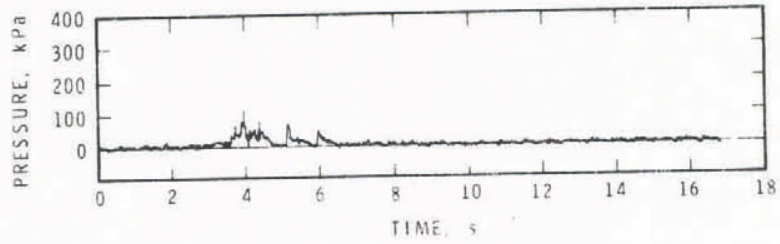

Fig.6. Pressure record for powder avalanche, from the large plate (Avalanche 80-12-26, No.1).

Table 1 also lists the duration of the avalanche waves or avalanche pressure record in seconds. This together with estimates of $\mathrm{V}$ makes it possible to specify the spatial length of the avalanches or debris waves.

ANALYSIS OF RESULTS FROM THE LARGE PLATE AND COMPARISON WITH SIMPLE THEORY

Some quantitative trends in the data for flowing avalanches (Table 1) may be specified, but it is not yet possible to supply quantitative estimates of design loads since the data are limited. It is a virtual certainty that the actual numbers in the analysis will change as more data become available. The maximum or peak pressures recorded are associated with impacts of solid debris chunks, peaks in density fluctuations, velocity surges, or a combination of these effects. As no information is available on velocity surges, the data were analysed based upon density fluctuations at constant speed, but this is only an approximation at best.

Maximum pressures, $P_{M}$, were analysed assuming that they are due to impacts of solid debris chunks or regimes of high flow density. Mellor (1968) gave a simple one-dimensional theory that accounts for compaction of snow upon impact by compressibility effects resulting from upstream propagation of a plastic wave. Using mass and momentum conservation across the wave front:

$$
\frac{P_{M}}{V^{2}}=\rho_{i}\left[1+\frac{\rho_{i}}{\rho_{f}-\rho_{i}}\right]=\rho_{e}
$$

where $P_{M}$ is in $P a$ and $V$ is in $\mathrm{m} / \mathrm{s}$. Equation 1 neglects elastic response so that it represents only a simple approximation to the actual physical situation. For analysis $\rho_{j}$ is taken as initial flow density and $\rho_{\mathrm{f}}$ as final density of compressed snow. A maximum value of $\rho_{f}=600 \mathrm{~kg} / \mathrm{m}^{3}$ is assumed, based upon observations of Wakahama and Sato (1977) that fracturing will occur rather than higher densities for loading rates resulting from speeds typical of avalanches. The ratio $\mathrm{P}_{\mathrm{M}} / \mathrm{V}^{2}$ may be interpreted as an effective flow density, $\rho$, which would have an approximate upper limit of $600 \mathrm{~kg} / \mathrm{m}^{3}$ for dry snow.
A regression analysis of the data yields the best fit for a power law with $P_{M}$ as a function of $V$ rather than a polynomial expansion in V. This analysis gives:

$$
\mathrm{P}_{\mathrm{M}} \sim \mathrm{V}^{1.98}
$$

with $R^{2}=0.717$ and $S=0.626$, where $R$ is the correlation coefficient and $S$ is standard error. This indicates a trend towards agreement with Equation 1. The range of speed, $\mathrm{V}$, is 8 to $34 \mathrm{~m} / \mathrm{s}$ (Table 1), with a mean of about $19 \mathrm{~m} / \mathrm{s}$.

The values of $P_{M} / V^{2}$ have a mean of $334 \mathrm{~kg} / \mathrm{m}^{3}$ and a standard deviation of $225 \mathrm{~kg} / \mathrm{m}^{3}$, with a range of 148 to $792 \mathrm{~kg} / \mathrm{m}^{3}$. The mean of these data implies a flow density for peak pressures $\left(\rho_{\mathrm{i}}\right)$ of about $215 \mathrm{~kg} / \mathrm{m}^{3}$ using Equation 1 and $\rho_{\mathrm{f}}=600 \mathrm{~kg} / \mathrm{m}^{3}$. If the density of the particles, $\rho_{p}$, is taken as the mean for observed Tupper No 1 debris $\left(390 \mathrm{~kg} / \mathrm{m}^{3}\right)$, these results imply that the volume fraction of solids is near $55 \%$, which is in approximate agreement with the recommendation of Schaerer (1973) that peak pressures may be approximated by $\mathrm{P}_{\mathrm{M}} \sim 1 / 2 \rho_{\mathrm{D}} \mathrm{V}^{2}$. An alternate picture is that a solid chunk covered about half the area of the plate. Mellor's theory is actually more appropriate for this case, but the concept of pressure breaks down because the effective area over which the load is applied varies with the size of the chunk, which is unknown.

For the analysis, flowing avalanches with dry and moist debris were grouped together and classified as dry. Field observations show that in most cases avalanches with moist debris began as dry ones and that the particles became moist by the time they reached the runout zone, presumably as a result of heat generated by collisions with other particles and by friction on the sliding surface over which the avalanche runs. This classification is supported by the similarity of pressure records for moist and dry avalanches in a number of cases.

For the data in Table 1, dry and moist avalanches have an average value $\frac{\mathrm{P}_{\mathrm{M}}}{\mathrm{V}^{2}}=450 \mathrm{~kg} / \mathrm{m}^{3}$ and wet avalanches an average value $\frac{P_{M}}{V^{2}}=290 \mathrm{~kg} / \mathrm{m}^{3}$,

indicating a trend towards higher peak pressures for dry avalanches at a given speed.

For average pressure, a simple fluid dynamic model is adopted. The average pressure, $\mathrm{P}$, for fluidized debris impinging on the plate is approximated as:

$$
\frac{\overline{\mathrm{P}}}{\mathrm{V}^{2}}=1 / 2 \bar{\rho} C_{\mathrm{D}}
$$

where $\bar{p}$ is average flow density and $C_{D}$ is a drag coefficient. For a circular plate with a free edge in turbulent fluid flow experimental data show $\mathrm{C}_{\mathrm{D}}$ is 1.1 for Reynolds numbers between $10^{3}$ and $10^{6}$ (Addison 1956). For laminar flow experimental data show that $C_{D}$ is a function of Reynolds number and that it is greater than the value for turbulent flow. Prandtl and Tietjens (1934) list an experimental value of 2 as typical of laminar flow.

A regression analysis of the data shows that it is described better by a power law than by a polynomial expression, i.e.:

$$
\overline{\mathrm{P}} \sim \mathrm{V}^{1.52}
$$

with $\mathrm{R}^{2}=0.834$ and $\mathrm{S}=0.338$. If $\mathrm{C}_{\mathrm{D}}$ is assumed constant, as data show in the fluid turbulent case, Equation 4 implies

$$
\bar{\rho} \sim \frac{1}{\sqrt{V}}
$$

This result will change when more data become available, but it shows a physically appealing trend towards a decrease in flow density and hence an 
increase in flow height with increasing speed. This is consistent with field observations.

The data in Table I show that the ratio $\overline{\mathrm{P}} / \mathrm{V}^{2}$ has a mean of $97 \mathrm{~kg} / \mathrm{m}^{3}$ and a standard deviation of 50 $\mathrm{kg} / \mathrm{m}^{3}$. With $C_{D}$ taken as 1.1 this implies an average flow density near $170 \mathrm{~kg} / \mathrm{m}^{3}$. If $\rho_{\mathrm{D}}$ is taken near the mean of Rogers Pass data, this implies an average volume fraction of solids in excess of $40 \%$ for wet and dry avalanches together.

Moist and dry avalanche data taken together show a mean value of $\overline{\mathrm{P}} / \mathrm{V}^{2}=70 \mathrm{~kg} / \mathrm{m}^{3}$, which may be compared with an average value $107 \mathrm{~kg} / \mathrm{m}^{3}$ for wet avalanches. This indicates that average flow densities are higher for wet avalanches if $C_{D}$ is assumed constant. For a value of $C_{D_{3}}=1.1$, a verage flow densities would be near $125 \mathrm{~kg} / \mathrm{m}^{3}$ and $195 \mathrm{~kg} / \mathrm{m}^{3}$ for dry and wet avalanches, respectively. For Tupper No. 1, from 1979 to 1984, estimates for 95 avalanches show an average value $\rho_{\mathrm{D}}=360 \mathrm{~kg} / \mathrm{m}^{3}$ for dry and moist debris and $\rho_{\mathrm{D}}$ $=500 \mathrm{~kg} / \mathrm{m}^{3}$ for wet debris, to give estimated average volume fraction of near $35 \%$ and $40 \%$, respectively. Caution has to be used in accepting these values; if the flows contain such high debris concentrations, the mechanical properties can differ substantially from the turbulent fluid dynamic modelling.

The pressure record of the small, dry powder avalanche on $80-12-26$ (Figure 6) has a peak pressure of $125 \mathrm{kPa}$ and an average pressure of $19 \mathrm{kPa}$, with a speed of $47 \mathrm{~m} / \mathrm{s}$. For these data $P_{M} / V^{2}=57 \mathrm{~kg} / \mathrm{m}^{3}$ and $\overline{\mathrm{P}} / \mathrm{V}^{2}=8.6 \mathrm{~kg} / \mathrm{m}^{3}$. Both values fall far below the averages of $450 \mathrm{~kg} / \mathrm{m}^{3}$ and $70 \mathrm{~kg} / \mathrm{m}^{3}$ for dry avalanches. The value $\overline{\mathrm{P}} / \mathrm{V}^{2}$ implies an average flow density near 15 $\mathrm{kg} / \mathrm{m}^{3}$ for $C_{D}=1.1$ and the volume fraction of solids may be less than $10 \%$ if debris particle densities are taken near estimated values for small dry avalanches.

Taken together, the data in Table 1 show that power law regression gives the best fit of $P_{M}$ versus $\bar{P}$. This relation is

$$
\mathrm{P}_{\mathrm{M}}=1.7 \overline{\mathrm{P}}^{1.22}
$$

with $\mathrm{R}^{2}=0.716$ and $\mathrm{S}=0.571$. Dry and moist avalanches together have an average value of $\mathrm{P}_{M} / \overline{\mathrm{P}}=$ 6.0 , whereas wet avalanches show an average value $\mathrm{P}_{\mathrm{M}} / \overline{\mathrm{P}}=2.6$. This supports the descriptive analysis of the pressure records and again indicates that average flow densities are lower for dry and moist avalanches for a given speed.

\section{COMPARISON WITH OTHER DATA}

Perla and others (1978) provided data from impact pressure drop tests as a function of snow density, using snow cylinders and an impact area of $0.196 \mathrm{~m}^{2}$ on a circular aluminum plate of the same thickness as was used in the present tests. Tests were made for snow densities in the range $252 \mathrm{~kg} / \mathrm{m}^{3}$ to $658 \mathrm{~kg} / \mathrm{m}^{3}$, with a mean near $385 \mathrm{~kg} / \mathrm{m}^{2}$ at one speed of $13.5 \mathrm{~m} / \mathrm{s}$.

A regression analysis of the data shows that a polynomial fit with $\rho_{i}$ is better than power law regression and gives the following relation:

$$
\frac{\mathrm{P}_{\mathrm{M}}}{\mathrm{V}^{2}}=\left[3.043 \rho_{\mathrm{i}}-1.927 \times 10^{-3} \rho_{\mathrm{i}}^{2}-486\right]
$$

with $\mathrm{R}^{2}=0.876$ and $\mathrm{S}=0.0688$.

If one assumes that peaks are due to single chunks, then for $\rho_{i}=\rho_{D}=390 \mathrm{~kg} / \mathrm{m}^{3}$, a mean value for Tupper No. 1 debris, this estimate yields $\mathrm{P}_{\mathrm{M}} / \mathrm{V}^{2}=$ $408 \mathrm{~kg} / \mathrm{m}^{3}$, which is greater than but close to the field measured value of $334 \mathrm{~kg} / \mathrm{m}^{3}$. The drop tests should give higher values than the actual measurements in the avalanches because the effective area of load transfer for a debris chunk would generally be less than the plate area, yielding lower pressure estimates if peaks were due to single debris chunks smaller than $0.5 \mathrm{~m}$ diameter. Also, the drop tests provide data for perpendicular loading near the plate center, whereas field data may represent off-center loading at different directions on the plate. This analysis provides some, although not conclusive, support for the concept that peaks are due to single chunks. Mellor's (1968) theory would be much more appropriate to apply to the solid impact data of Perla and others (1978) than for avalanche flows if fluidized debris had a volume fraction of solids of $50 \%$ or less. Application of Equation 1 with $\rho_{r}=600 \mathrm{~kg} / \mathrm{m}^{3}$ indicates that the compaction term is a correction of only a few percent for the mean value of the data of Perla and others (1978).

Another important data set is provided from France by Eybert-Berard and others (1978). These data consist of field measurements of $\mathrm{P}_{\mathrm{M}}, \overline{\mathrm{P}}$ and $\mathrm{V}$ for 15 avalanches, of which only two are wet avalanches. For comparison V is taken as measured avalanche frontal speed, and if that is not available $\mathrm{V}$ is taken as the maximum speed estimated from a flowmeter mounted on the pressure stand. The French data are for speeds of $10-28 \mathrm{~m} / \mathrm{s}$ with a mean near $17 \mathrm{~m} / \mathrm{s}$. The debris density showed a mean value $\rho_{D}=327$ $\mathrm{kg} / \mathrm{m}^{3}$, with a range of $165-600 \mathrm{~kg} / \mathrm{m}^{3}$, which is somewhat lower on the average than the Rogers Pass data, perhaps owing to a greater proportion of dry avalanches.

The regression analysis showed that a polynomial function is the best fit for $P_{M}$ as a function of $V\left(R^{2}=\right.$ 0.643). For comparison, a power law regression gives $P_{M} \sim V^{1.28}$ with $R^{2}=0.609$ and $S=0.330$ indicating weaker speed dependence than the Rogers Pass data. The mean value of $\mathrm{P}_{\mathrm{M}} / \mathrm{V}^{2}$ is $340 \mathrm{~kg} / \mathrm{m}^{3}$ with a standard deviation of $149 \mathrm{~kg} / \mathrm{m}^{3}$ indicating slightly higher values than Rogers Pass data, although average debris density is less. The agreement for this parameter is quite good and it is also consistent with the solid impact of Perla and others (1978).

A regression analysis of data for average pressures showed that a polynomial expansion gave the best fit $\left(R^{2}=0.643\right.$ for terms up to $\left.V^{2}\right)$. For comparison, power law regression shows $\overline{\mathrm{P}} \sim \mathrm{V}^{1.30}$ with $\mathrm{R}^{2}=0.517$ and $\mathrm{S}$ $=0.404$, indicating again a weaker speed dependence as compared to the Rogers Pass data.

The ratio $\overline{\mathrm{P}} / \mathrm{V}^{2}$ for French data has a mean near $150 \mathrm{~kg} / \mathrm{m}^{3}$ and a standard deviation $62 \mathrm{~kg} / \mathrm{m}^{3}$. These values are higher than those determined for the Rogers Pass data by a factor of roughly 2. Application of the fluid dynamic equation 3 to this value yields the conclusion that $\bar{p} \times C_{D}=300 \mathrm{~kg} / \mathrm{m}^{3}$. For a drag coefficient near 1 for the French experiments (Eybert-Berard and others 1978) the conclusion is that average implied flow densities approximate the average value of $\rho_{D}$ for this set of avalanches or that the volume fraction of solids is about $100 \%$. One possible explanation for this physically unrealistic result is the size effect. The pressure sensors in the French experiments are $0.1 \mathrm{~m}$ in diameter, implying a sensor area 25 times smaller than those used to obtain the Rogers Pass data. The concept of average pressure would lose meaning as the sensor size approaches the debris particle size.

For the French data the mean value of the ratio $\mathrm{P}_{\mathrm{M}} / \overline{\mathrm{P}}$ is near 2.3. This mean value would approach the Rogers Pass mean value for dry avalanches if the values of $\bar{P}$ are higher by a factor of 2 for the French data due perhaps to size effects.

Kotlyakov and others (1977) observed avalanche impact pressures using steel cones that penetrated aluminum plates. No concurrent speed data were given. This type of measurement system is known to provide estimates of impact pressures that are too high (e.g. Shimizu and others 1980). Kotlyakov and others (1977) recommend that maximum and average pressures be estimated by $P_{M}=4.8 \rho_{D} V^{2}$ and $\bar{P}=2 \rho_{D} V^{2}$, which is about five to ten times the estimates, based on the Rogers Pass data, the data of Perla and others (1978) or the data of Eybert-Berard and others (1978). The implied ratio $\mathrm{P}_{\mathrm{M}} / \overline{\mathrm{P}}$ is approximately that of the French data, however.

\section{CONCLUSIONS AND DISCUSSION}

Pressure and speed data on flowing avalanches measured at Rogers Pass, B.C., indicate the following trends: 
1. Data from small cells consistently show that frequency of particle impacts and hence flow density increase through the cross-section of wet and dry avalanches from the top of the flow to the sliding surface.

2. A size effect is clearly evident when data from small cells are compared with those obtained with a large pressure plate. An order of magnitude higher pressures were observed for peak pressures measured with small cells.

3. Dry avalanches generally have higher values of peak pressure and a higher ratio of peak-to-average pressure, by about a factor of 2 , than wet avalanches. The values $P_{M} / V^{2}$ and $\bar{P} / V^{2}$ indicate reasonable values of peak and average flow densities with volume fraction of solids estimated to be $55 \%$ or less.

Measurements from a high-speed powder avalanche indicate values of $\mathrm{P}_{\mathrm{M}} / \mathrm{V}^{2}$ and $\mathrm{P} / \mathrm{V}^{2}$ much lower than those for flowing avalanches, with an average flow density an order of magnitude lower than that for dry flowing avalanches and a volume fraction of solids near $10 \%$.

Comparison of Rogers Pass data with other data indicates the following:

1. The ratio $P_{M} / V^{2}$ is slightly lower than that determined by Eybert-Berard and others (1978) from avalanche observations and slightly lower than the solid impact experiments of Perla and others (1978), as would be expected from the physical differences. The supposition that peak pressures are due to high density clusters of particles or large particle impacts is supported.

2. Comparison of $\overline{\mathrm{P}} / \mathrm{V}^{2}$ indicates that the Rogers Pass data give values about half those of Eybert-Berard and others (1978). This may be due to the size effect for the measurement gauges.

The Rogers Pass data show a tendency for dry, flowing avalanches to have the highest peak pressures and highest speeds. There are indications also that dry avalanches have lower average flow densities. This latter may be due to lower friction at the ground. Field experience confirms these trends in the measurements. This leads to the conclusion that dry, flowing avalanches must be considered as the basis for design impact forces on structures and estimates of maximum avalanche runout distances. It is believed, however, that more data are needed to permit specifying accurate design loads.

With respect to design peak pressures, it may be of interest that application of Mellor's (1968) theory (Equation 1) coupled with Wakahama and Sato's (1977) maximum density estimate implies that $\mathrm{P}_{\mathrm{M}} / \mathrm{V}^{2}$ should have an approximate upper limit near $600 \mathrm{Mg} / \mathrm{m}^{3}$, the value for dry, close-packed snow, assuming that a block of snow covers the entire plate and strikes it perpendicularly. The mean and standard deviations of $\mathrm{P}_{\mathrm{M}} / \mathrm{V}^{2}$ imply that the $95 \%$ confidence limit of the data is $700 \mathrm{~kg} / \mathrm{m}^{3}$ for Rogers Pass and $570 \mathrm{~kg} / \mathrm{m}^{3}$ for the data of Eybert-Berard and others, respectively, assuming Gaussian distributions. The actual data have higher ranges, but this could be due to particle size greater than the sensor size, experimental errors, or water-soaked dense snow. Similar conclusions follow from analysis of the data of Perla and others (1978).

Although enough data are now available to indicate trends in flow characteristics and impact pressures for flowing avalanches, more are needed to enable design loads to be specified with a good degree of confidence.

\section{ACKNOWLEDGEMENTS}

The authors wish to thank Paul Anhorn and Brant Benum for assistance with the field measurements and the Superintendent and Staff of Glacier National Park for their co-operation and support. This paper is a contribution from the Division of Building Research, National Research Council of Canada, and is published with the approval of the Director of the Division.

\section{REFERENCES}

Addison $\mathrm{H} 1956$ A treatise on applied hydraulics. London, Chapman and Hall

Bon Mardion G, Coche G, Eybert-Berard A, Jourdan P, Perroud P, Rey L 1974 Mésures dynamiques dans l'avalanche. Premiers resultats experimentaux. Note CENG/ASP No 74-01. Communication présentée à la réunion de la Section de Glaciologie de la Société Hydrotechnique de France, Paris, les 7 et 8 Mars 1974

Eybert-Berard A, Perroud P, Brugnot G, Mura R, Rey L 1978 Mésures dynamiques dans l'avalanche. Resultats éxperimentaux du col du Lautaret (1972-78). Comptes rendus: Deuxieme Recontre Internationale sur la Neige tes Avalanches, Grenoble, France: 203-212

Kotlyakov V M, Rzhevskiy R N, Samolov V A 1977 The dynamics of avalanching in the Khibins. Journal of Glaciology 19(81): 431-439

Mellor M 1968 Avalanches. Cold Regions Science and Engineering, Part III, Section A-3. US Army CRREL, Hanover, N.H.

Perla R, Beck T, Banner J 1978 Impact force of snow. Ottawa, Environment Canada, Inland Waters Directorate. National Hydrology Research Institute (NHRI Paper 2).

Prandtl L, Tietjens O G 1934 Applied hydro- and aeromechanics. New York, Dover Publications

Salway A 1978 A seismic and pressure transducer system for monitoring velocities and impact pressures of snow avalanches. Arctic and Alpine Research 10(4): 769-774

Schaerer P A 1973 Observations of avalanche impact pressures. In Advances in North American Avalanche Technology: 1972 Symposium. US Dept. Agriculture. Forest Service, General Technical Report RM-3, Ft Collins, Colorado: 51-54

Schaerer P A, Salway A 1980 Seismic and impact monitoring of flowing avalanches. Journal of Glaciology 26(94): 179-187

Shimizu H, Huzoika T, Akitaya E, Narita H, Nakagawa M, Kawada K 1980 A study on high speed avalanches in the Kurobe canyon, Japan. Journal of Glaciology 26(94): 141-151

Wakahama G, Sato A 1977 Propagation of a plastic wave in snow. Journal of Glaciology 19(81): 175-183 